\title{
Effects of $\mathrm{MoO}_{3}$ Addition on Spectroscopic Properties of Lithium Zinc Borate Glass
}

\author{
B. Thirumala Rao ${ }^{1}$, Sandhya Cole ${ }^{2}$, P. Syam Prasad ${ }^{3, *}$ \\ ${ }^{1}$ Department of Basic science, Vishnu institute of Technology, Bhimavaram, India \\ ${ }^{2}$ Department of Physics, Acharya Nagarjuna University, India \\ ${ }^{3}$ Department of Physics, National Institute of Technology, Warangal, India
}

\begin{abstract}
The paper deals with the spectroscopic properties of $\mathrm{Li}_{2} \mathrm{O}-\mathrm{ZnO}-\mathrm{B}_{2} \mathrm{O}_{3}$ glass containing different concentrations of $\mathrm{MoO}_{3}$ (ranging from 1 to $5 \mathrm{~mol} \%$ ) were prepared by melt quenching. Spectroscopic (infrared, optical absorption spectra and ESR) properties of these glasses have been carried out. The Optical absorption Spectrum contains one broad absorption band at $681 \mathrm{~nm}$, this attributed to the excitation of $\mathrm{Mo}^{5+}\left(4 \mathrm{~d}^{1}\right)$ ion. ESR studies reveal Molybdenum ions are expected to exist mainly in the $\mathrm{Mo}^{6+}$ state in the glass network. As the concentration of $\mathrm{MoO}_{3}$ is increased, especially beyond $5.0 \mathrm{~mol} \%$, the colour of the glasses increased, that indicating the reduction of molybdenum ions from the $\mathrm{Mo}^{6+}$ state to the $\mathrm{Mo}^{5+}$ state. ESR, IR and Optical absorption spectra of paramagnetic ion in the above glasses reveal that the site symmetry of the transition metal ion is elongated octahedral.
\end{abstract}

Keywords $\mathrm{MoO}_{3}$, ESR Spectra, IR Spectra, Optical Properties

\section{Introduction}

The glasses containing transition metal ions (TMI) came into prominence because of their notable spectroscopic properties and their suitability for fiber optic communications, luminescent solar energy concentrators $(\text { LSC })^{1}$. Among the conventional glasses, borate glasses have been known to be excellent host materials for transition metal oxides because of their glass forming nature compare to other conventional glass systems. Borate glasses are used as wave-guides, electro-optic switches, electro-optic modulators, magneto-optic materials, solid-state laser materials and non-linear optical parametric converters ${ }^{2-4}$. In addition, they are often used as dielectric and insulating materials and it is known that borate glass constitute a good shield against IR radiation ${ }^{5}$. In general $\mathrm{B}_{2} \mathrm{O}_{3}$ glasses contain the greatest amount of boric oxide that shows a minimum expansion, a property which is of great importance in obtaining thermal durability. It also decreases the tendency for glass to devitrify or crystallize. $\mathrm{B}_{2} \mathrm{O}_{3}$ is a basic glass former because of its higher bond strength, lower cation size and smaller heat of fusion. Among the three modifier oxides, viz., $\mathrm{ZnO}, \mathrm{PbO}, \mathrm{CaO}$; $\mathrm{ZnO}$ having covalent character ${ }^{6}$, is expected to shorten the time taken for solidification of glasses during the quenching process. $\mathrm{ZnO}$, reduces the

* Corresponding author:

syam9405@gmail.com (Syam Prasad)

Published online at http://journal.sapub.org/pc

Copyright (C) 2012 Scientific \& Academic Publishing. All Rights Reserved coefficient of thermal expansion, thus making possible the production of glass products of high resistance to thermal shock. Molybdenum ions in the glasses have been the subject of many investigations due to their catalytic properties. The ions of molybdenum inculcate high activity and selectivity in a series of oxidation reactions of practical importance in the glass matrices ${ }^{7,8}$. Mo-O bond in molybdenum hexavalent oxide is identified as covalent. The Mo ion exists at least in two stable valence states viz., $\mathrm{Mo}(\mathrm{V})$ and $\mathrm{Mo}(\mathrm{VI})$ in the glass network. Earlier ESR studies on the glasses containing molybdenum ions have identified the presence of octahedrally coordinated $\mathrm{Mo}(\mathrm{V})$ ions along with distorted octahedrons approaching tetragons ${ }^{9,10}$. These ions act both as network formers as well as network modifiers depending upon their concentration and nature of the host network. The $\mathrm{Mo}^{6+}$ ions are expected to participate in the glass network with tetrahedral $\mathrm{MoO}_{4}{ }^{2-}$ structural units and may alternate with $\mathrm{BO}_{4}$ tetrahedral units. Most of the studies available on $\mathrm{MoO}_{3}$ containing glasses are on the understanding of their structure by spectroscopic investigations ${ }^{11,12}$ and ionic conductivity studies ${ }^{13}$.

In the present contribution the influence of $\mathrm{MoO}_{3}$ in varying concentrations, on resonance and absorption properties of lithium-zinc-borate glasses are described in some detail. Optical band gaps for both direct and indirect transitions and Urbach energies were calculated and those glasses were also characterized by EPR and IR studies.

\section{Experimental}


The glasses of the system $10 \mathrm{Li}_{2} \mathrm{O}-(10-\mathrm{x}) \mathrm{ZnO}-80 \mathrm{~B}_{2} \mathrm{O}_{3}$ : $\mathrm{xMoO}_{3}(\mathrm{x}=0,1,2,3,4$ and $5 \mathrm{~mol} \%)$ have been prepared by adopting the melt quenching technique. The raw materials used were analytical pure $\mathrm{ZnO}, \mathrm{Li}_{2} \mathrm{CO}_{3}, \mathrm{H}_{3} \mathrm{BO}_{3}$. Appropriate amounts of weighed chemicals were grounded thoroughly in a mortar to produce homogeneous mixture. This homogenized mixture was then placed in porcelain crucibles and melted in an electrical furnace in air at $870^{\circ} \mathrm{C}-920^{\circ} \mathrm{C}$ for half an hour until a bubble free liquid was formed .The melt was then quenched to room temperature in air by pouring it on to a Brass slab. The glasses thus obtained were transparent and in color. Details of experimental procedure and calculations are similar to the earlier work ${ }^{14}$.

\section{Results and Discussion}

\subsection{Absorption Spectra}

The Optical absorption spectra of the $\mathrm{Li}_{2} \mathrm{O}-\mathrm{ZnO}-\mathrm{B}_{2} \mathrm{O}_{3}$ : $\mathrm{MoO}_{3}$ glasses recorded at room temperature in the wavelength range $400 \mathrm{~nm}-1400 \mathrm{~nm}$. The Optical absorption spectrum of molybdenum doped lithium zinc borate glass (with $\mathrm{x}=3 \mathrm{~mol} \%$ ) is shown in the Fig. 1. The absorption edge observed is observed to shift towards higher wavelength side. The spectrum of $\mathrm{MoO}_{3}$ free glasses does not exhibit any absorption band. But small amount of molybdenum is added to glasses matrix shows a broad optical absorption band at about $681 \mathrm{~nm}^{15}$. The intensity of this band was observed to increase gradually as the concentration of $\mathrm{MoO}_{3}$ increased. From an extrapolation of the linear portion of the curves of Fig. 2(a), 2(b), 2(c), gives direct, indirect band and Urbach energy gap so determined are presented in Table I. The values of direct and indirect band gap energies, decreases from $\mathrm{M}_{1}$ to $\mathrm{M}_{5}$.

\subsection{EPR Spectra}

The ESR spectra of the glasses recorded at room temperature exhibit signals consisting of a central line surrounded by smaller satellites at about $\mathrm{g} \|=1.9286$ and $\mathrm{g} \perp=1.9486$ for $\mathrm{M}_{3}$ glass system and is shown in Fig.3. The central line arises from even molybdenum isotopes $(\mathrm{I}=0)$ where as satellite lines correspond to the hyperfine structure from odd ${ }^{95} \mathrm{Mo}$ and ${ }^{97} \mathrm{Mo}(\mathrm{I}=5 / 2)$ isotopes. The spectrums closely resembles that of the molybdenum ion in most oxide glasses, from the spectral analysis, the spin-Hamiltonian parameters were calculated using the following equation and are presented in the Table II. The EPR spectra are analyzed using spin-Hamiltonian:

$$
\mathrm{H}=\mathrm{g}_{\|} \beta \mathrm{H}_{\mathrm{z}} \mathrm{S}_{\mathrm{z}}+\mathrm{g}_{\perp} \beta\left(\mathrm{H}_{\mathrm{x}} \mathrm{S}_{\mathrm{x}}+\mathrm{H}_{\mathrm{y}} \mathrm{S}_{\mathrm{y}}\right)+\mathrm{A}_{\|} \mathrm{S}_{\mathrm{z}} \mathrm{I}_{\mathrm{z}}+\mathrm{A}_{\perp}\left(\mathrm{S}_{\mathrm{x}} \mathrm{I}_{\mathrm{x}}+\mathrm{S}_{\mathrm{y}} \mathrm{I}_{\mathrm{y}}\right)
$$

Here $Z$ is the symmetric axis, $\beta$ is the Bohr magneton, $S$ and $I$ are the electron and nuclear spin operators, $H_{x}, H_{y}$ and $H_{z}$ are the static magnetic field components, $\mathrm{g}_{\|}$and $\mathrm{g}_{\perp}$ are the parallel and perpendicular components of the $\mathrm{g}$ tensor and, $\mathrm{A}_{\|}$and $\mathrm{A}_{\perp}$ are the parallel and perpendicular components of the hyperfine tensor $\mathrm{A}$. The values of $\mathrm{A}_{\|}$are calculated using the following equations.

$$
\mathrm{H}_{\|}(-3 / 2)-\mathrm{H}_{\|}(+3 / 2)=3 \mathrm{~A}_{\|}
$$

The analysis of ESR spectra of these samples suggest that $\mathrm{Mo}^{5+}$ ions are essentially coordinated in these glass ceramics by five oxygen ligands in a square pyramidal form $\mathrm{C}_{4 \mathrm{v}}$ symmetry with a $\mathrm{Mo}=\mathrm{O}$ double bond ${ }^{16}$.

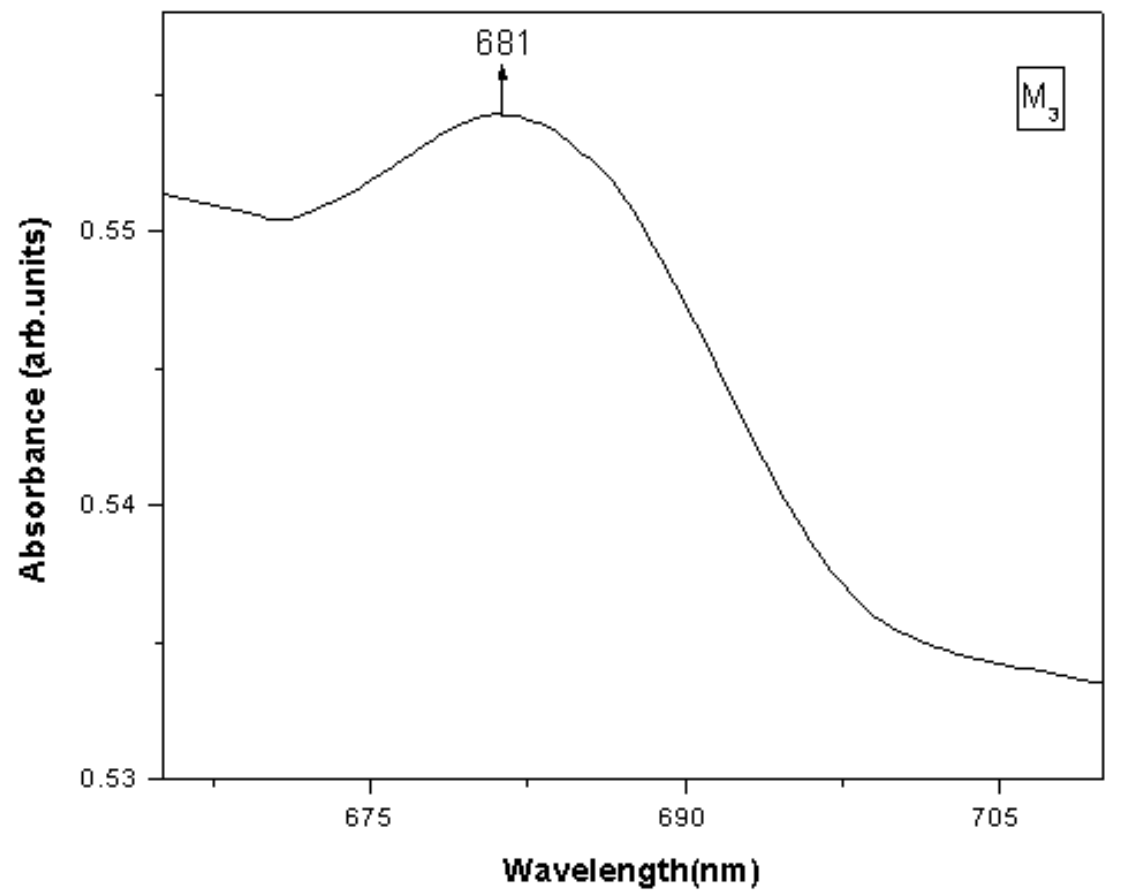

Figure 1. Optical absorption spectrum of Lithium-Zinc-Borate glass system containing $3 \mathrm{~mol} \%$ of $\mathrm{Mo}^{+5}$ ions at room temperature 


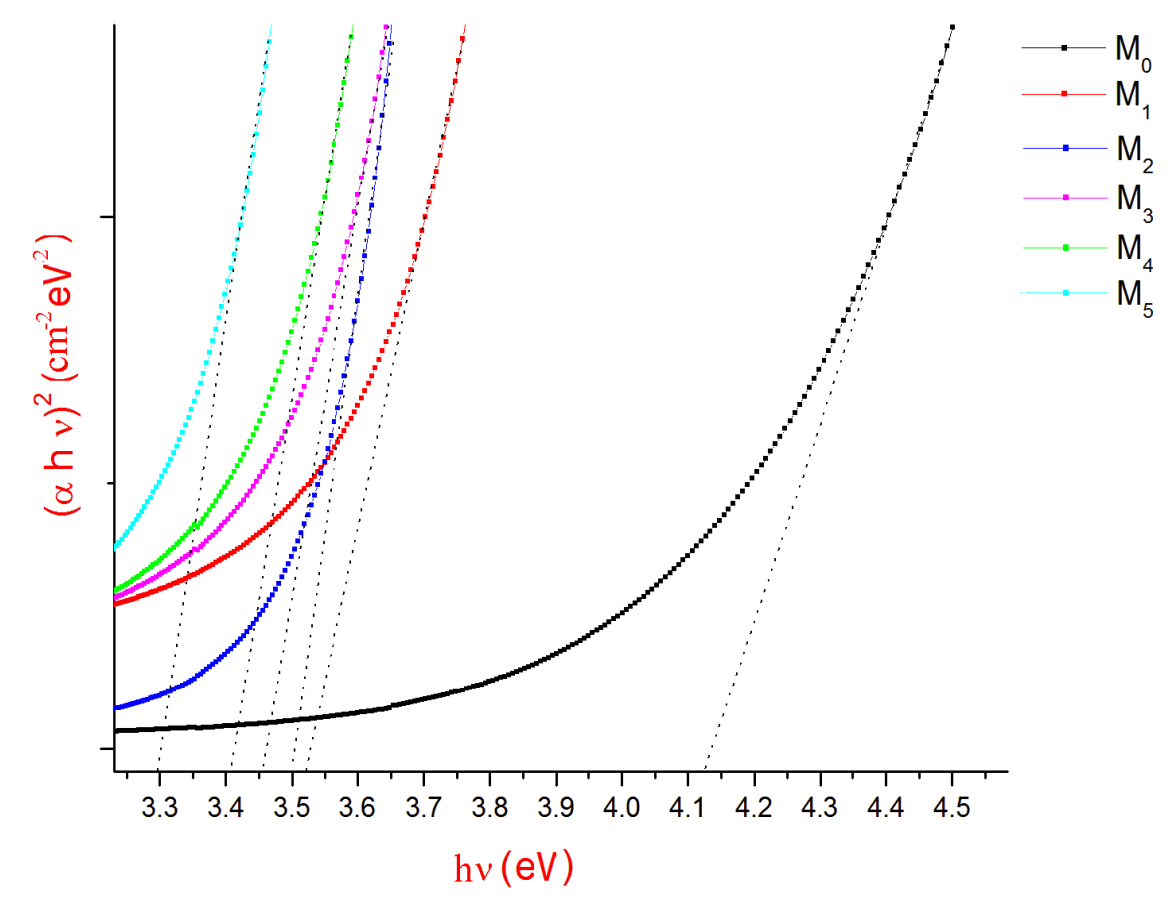

Figure 2(a). A plot between $(\alpha h v)^{2}$ and $h v$ for $\mathrm{M}_{0}, \mathrm{M}_{1}, \mathrm{M}_{2}, \mathrm{M}_{3}, \mathrm{M}_{4}$ and $\mathrm{M}_{5}$ glass samples

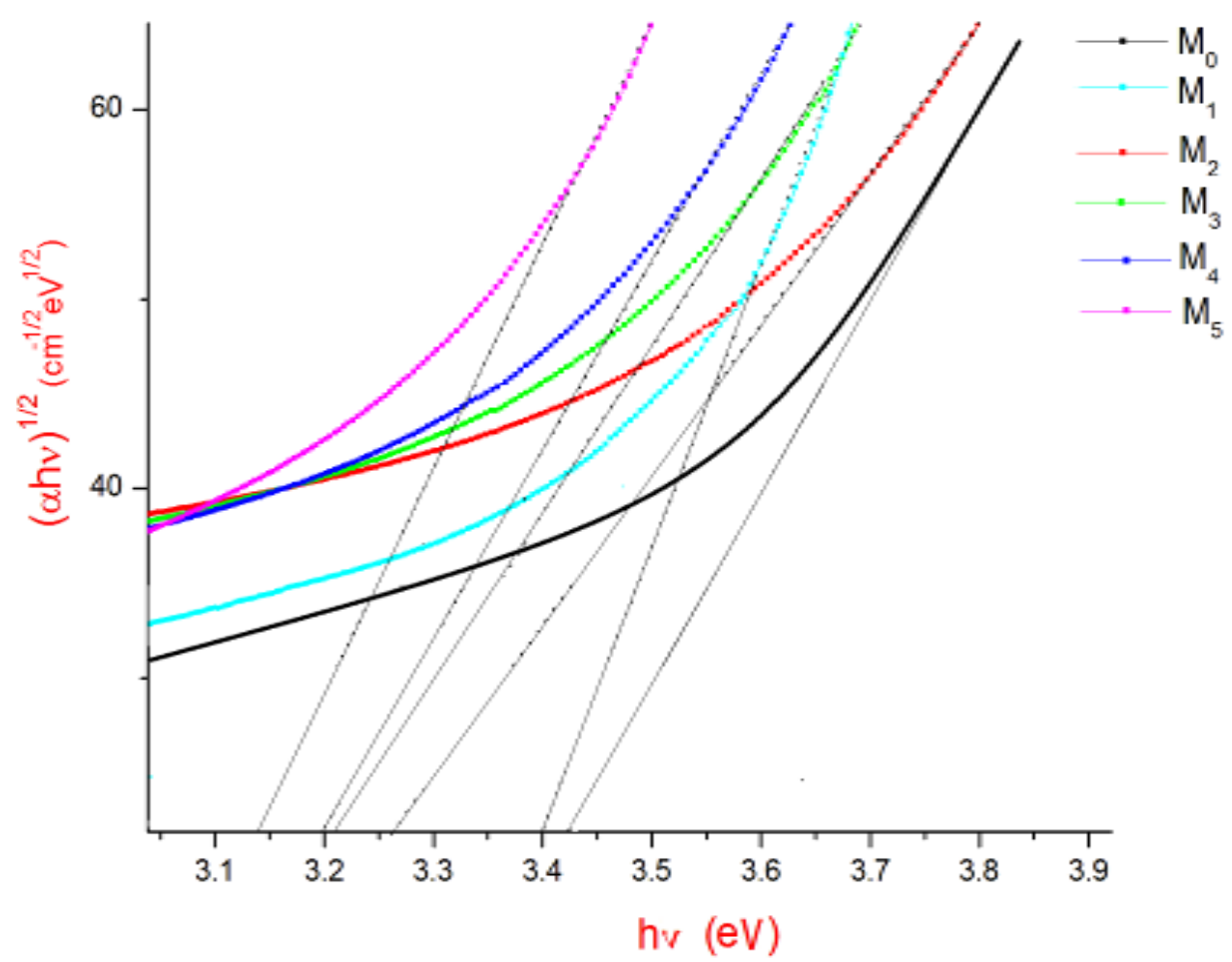

Figure 2(b). A plot between $(\alpha h v)^{1 / 2}$ and $h v$ for $\mathrm{M}_{0}, \mathrm{M}_{1}, \mathrm{M}_{2}, \mathrm{M}_{3}, \mathrm{M}_{4}$ and $\mathrm{M}_{5}$ glass samples 


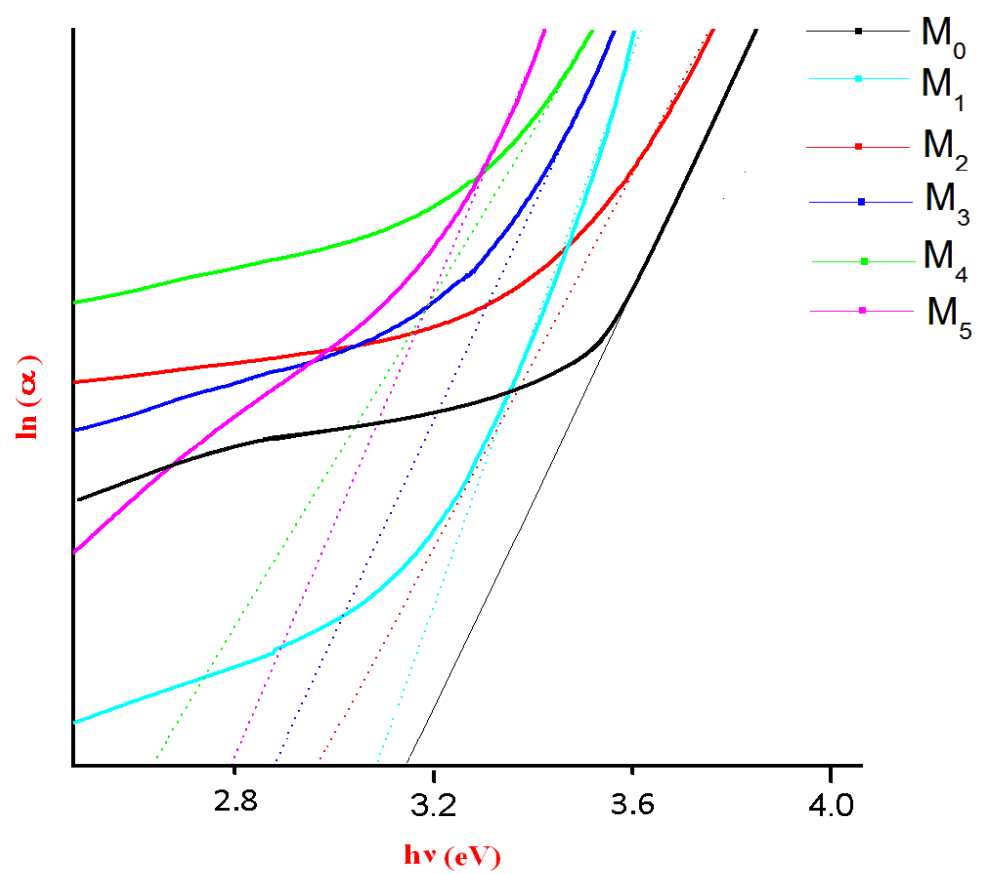

Figure 2 (c). A plot between $\ln (\alpha)$ and $h v$ for $M_{0}, M_{1}, M_{2}, M_{3}, M_{4}$ and $M_{5}$ glass samples

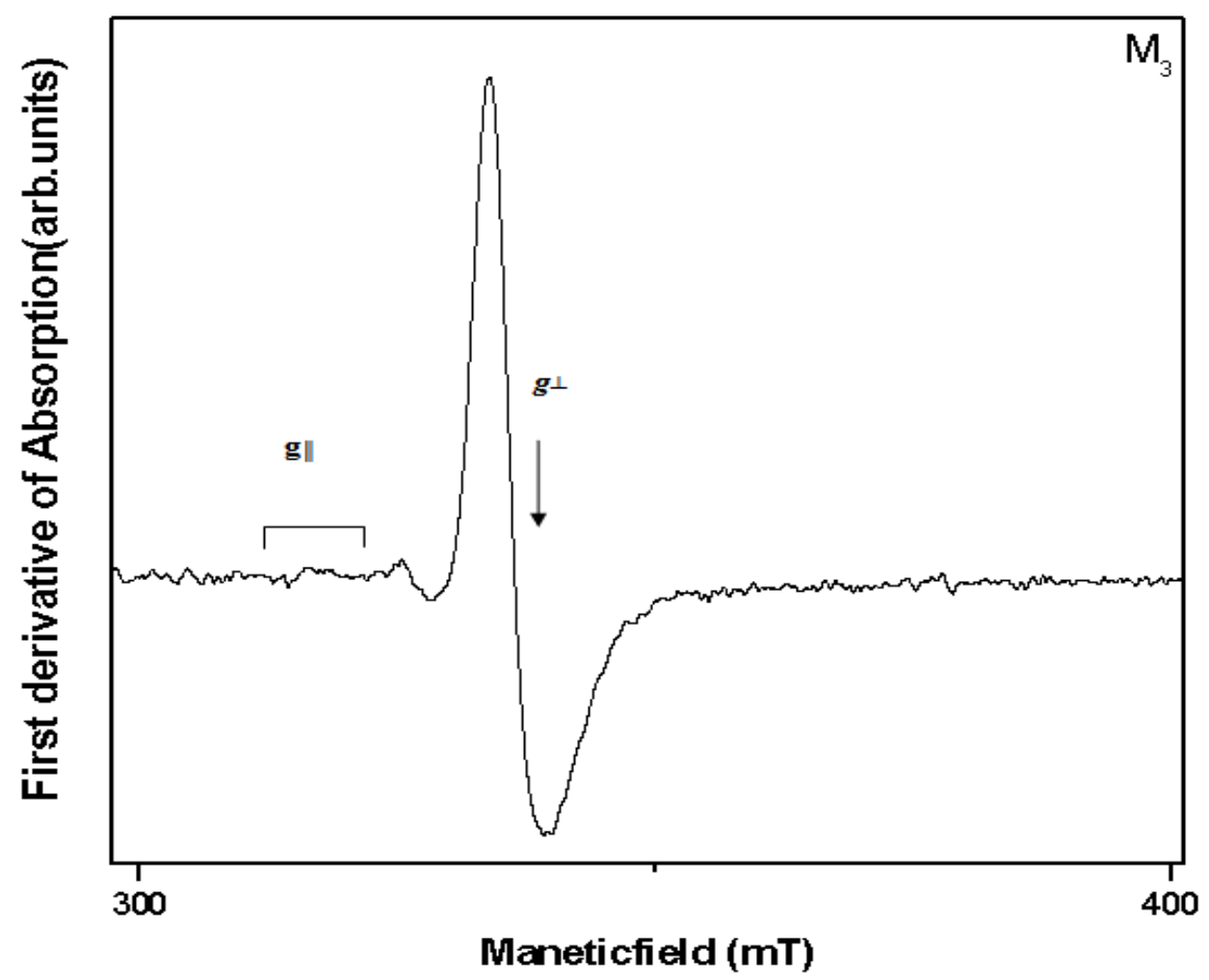

Figure 3. EPR spectra of $\mathrm{M}_{3}$ glass sample $(v=9.205 \mathrm{GHz})$ 


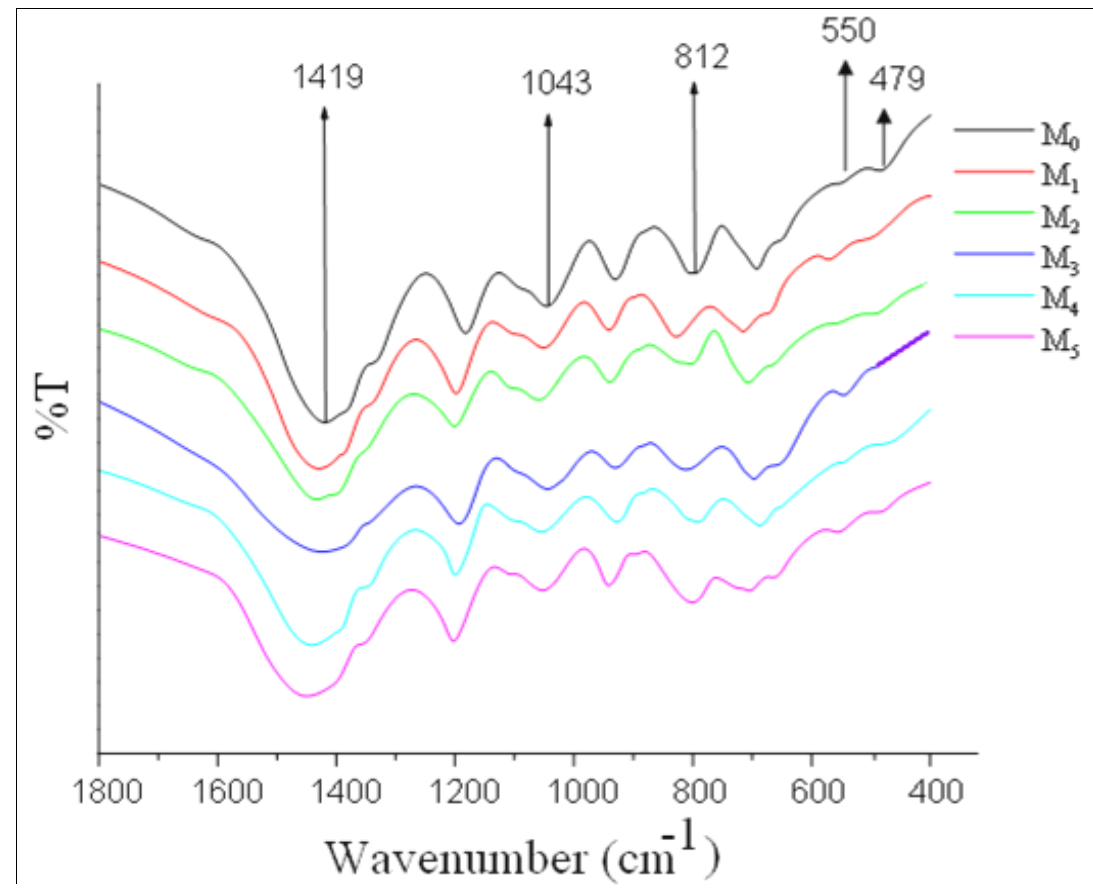

Figure 4. IR spectra of the $\mathrm{M}_{0}, \mathrm{M}_{1}, \mathrm{M}_{2}, \mathrm{M}_{3}, \mathrm{M}_{4}$ and $\mathrm{M}_{5}$ glass samples

Table I. Summary of the data on optical absorption spectra $\mathrm{Li}_{2} \mathrm{O}-\mathrm{ZnO}-\mathrm{B}_{2} \mathrm{O}_{3}: \mathrm{MoO}_{3}$ glasses

\begin{tabular}{cccccc}
\hline $\begin{array}{c}\text { Glass } \\
\text { Code }\end{array}$ & Cut-off wavelength(nm) & Band position(nm) & $\begin{array}{c}\text { Direct band } \\
\text { gap(eV) }\end{array}$ & $\begin{array}{c}\text { Indirect } \\
\text { band gap(eV) }\end{array}$ & $\begin{array}{c}\text { Urbach } \\
\text { Energy(eV) }\end{array}$ \\
\hline $\mathrm{M}_{0}$ & 259 & 670 & 4.13 & 3.42 & 0.316 \\
$\mathrm{M}_{1}$ & 310 & 672 & 3.53 & 3.49 & 0.320 \\
$\mathrm{M}_{2}$ & 327 & 675 & 3.50 & 3.22 & 0.335 \\
$\mathrm{M}_{3}$ & 332 & 681 & 3.46 & 3.20 & 0.346 \\
$\mathrm{M}_{4}$ & 333 & 683 & 3.41 & 3.19 & 0.358 \\
$\mathrm{M}_{5}$ & 348 & 691 & 3.29 & 3.14 & 0.380 \\
\hline
\end{tabular}

Table II. EPR data of $\mathrm{Li}_{2} \mathrm{O}-\mathrm{ZnO}-\mathrm{B}_{2} \mathrm{O}_{3}: \mathrm{MoO}_{3}$ glasses

\begin{tabular}{ccccc}
\hline Glass Code & $\mathrm{g}_{\|}$ & $g_{\perp}$ & $\begin{array}{c}\mathrm{A} \| \\
\left(\mathrm{x} 10^{-4} \mathrm{~cm}^{-1}\right)\end{array}$ & $\begin{array}{c}\mathrm{A} \perp \\
\left(\times 10^{-4} \mathrm{~cm}^{-1}\right)\end{array}$ \\
\hline $\mathrm{M}_{1}$ & 1.9448 & 1.9681 & 129.04 & 31.52 \\
$\mathrm{M}_{2}$ & 1.9391 & 1.9535 & 129.42 & 30.23 \\
$\mathrm{M}_{3}$ & 1.9286 & 1.9486 & 129.12 & 30.32 \\
$\mathrm{M}_{4}$ & 1.9114 & 1.9325 & 128.17 & 29.03 \\
$\mathrm{M}_{5}$ & 1.9093 & 1.9296 & 127.68 & 29.52 \\
\hline
\end{tabular}

Table III. The summary of various band positions of IR spectra of $\mathrm{Li}_{2} \mathrm{O}-\mathrm{ZnO}-\mathrm{B}_{2} \mathrm{O}_{3}: \mathrm{MoO}_{3}$ glasses

\begin{tabular}{|c|c|c|c|c|c|}
\hline $\begin{array}{l}\text { Glass } \\
\text { Code }\end{array}$ & $\begin{array}{c}\text { Trigonal }\left[\mathrm{BO}_{3}\right] \\
\text { units } \\
\left(\mathrm{cm}^{-1}\right) \\
\end{array}$ & $\begin{array}{c}\text { Stretching } \\
\text { vibrations } \\
\text { of }\left[\mathrm{BO}_{4}\right] \text { Units } \\
\left(\mathrm{cm}^{-1}\right) \\
\end{array}$ & $\begin{array}{c}\mathrm{v}_{1} \text { vibrational modes } \\
\text { of }\left[\mathrm{MoO}_{4}\right]^{2-} \\
\text { tetrahedral units } \\
\left(\mathrm{cm}^{-1}\right)\end{array}$ & $\begin{array}{c}\mathrm{v}_{3} \text { vibrational modes } \\
\text { of }\left[\mathrm{MoO}_{4}\right]^{6-} / \mathrm{Zn}-\mathrm{O} \\
\text { tetrahedral units } \\
\left(\mathrm{cm}^{-1}\right)\end{array}$ & $\begin{array}{c}\text { Vibrations of } \mathrm{ZnO}_{4} \\
\text { structural } \\
\text { units }\left(\mathrm{cm}^{-1}\right)\end{array}$ \\
\hline $\mathrm{M}_{0}$ & 1336 & 1047 & - & - & 479 \\
\hline $\mathrm{M}_{1}$ & 1340 & 1047 & 811 & 550 & 479 \\
\hline $\mathrm{M}_{2}$ & 1340 & 1049 & 812 & 550 & 478 \\
\hline $\mathrm{M}_{3}$ & 1342 & 1051 & 809 & 550 & 475 \\
\hline $\mathrm{M}_{4}$ & 1340 & 1049 & 808 & 550 & 474 \\
\hline $\mathrm{M}_{5}$ & 1336 & 1047 & 807 & 548 & 479 \\
\hline
\end{tabular}




\subsection{Infrared Spectra}

The prominent IR bands shown in Fig. 4 are observed for $\mathrm{Li}_{2} \mathrm{O}-\mathrm{ZnO}-\mathrm{B}_{2} \mathrm{O}_{3}: \mathrm{MoO}_{3}$ glasses and these bands are effectively influenced by the molybdenum content in the glasses network. The molybdenum free glasses exhibited in the regions $1300-1450 \mathrm{~cm}^{-1}, 1100-1200 \mathrm{~cm}^{-1}$. These bands are identified as stretching relaxations of B-O bonds of the trigonal $\mathrm{BO}_{3}$ units. Broad absorption bands are observed at $1050-900 \mathrm{~cm}^{-1}$ and $800-650 \mathrm{~cm}^{-1}$; these bands are identified due to stretching vibrations of the $\left[\mathrm{BO}_{4}\right]$ units. A band at 525 $\mathrm{cm}^{-1}$ is due to $\mathrm{Zn}-\mathrm{O}$ tetrahedral units and a band due to vibrations of $\mathrm{ZnO}_{4}$ structural units is located at about 470 $\mathrm{cm}^{-1}$ in the spectra of all the glasses ${ }^{17}$. When molybdenum is added, two new bands attributed, to $v_{1}$ and $v_{3}$ vibrational modes of $\left[\mathrm{MoO}_{4}\right]^{2-}$ tetrahedral units and $\left[\mathrm{MoO}_{6}\right]^{6-}$ have also been located at about 810 and $550 \mathrm{~cm}^{-1}$ is observed. The summary of various band position of $\mathrm{Li}_{2} \mathrm{O}-\mathrm{ZnO}-\mathrm{B}_{2} \mathrm{O}_{3}: \mathrm{MoO}_{3}$ is furnished in the Table III.

\section{Conclusions}

The conclusions drawn from analysis of the results of the various properties of $\mathrm{Li}_{2} \mathrm{O}-\mathrm{ZnO}-\mathrm{B}_{2} \mathrm{O}_{3}: \mathrm{MoO}_{3}$ glasses reported in this study are as follows:

- The Optical absorption Spectra of $\mathrm{Li}_{2} \mathrm{O}-\mathrm{ZnO}-\mathrm{B}_{2} \mathrm{O}_{3}$ : $\mathrm{MoO}_{3}$ glasses exhibits bands associated with transitions at $\mathrm{Mo}^{5+}$ ions, indicating that the molybdenum ions is in pentavalent state, in addition to tetravalent and hexavalent states respectively in these glass samples.

- The EPR Spectra of these glasses exhibit a signal consisting of a triplet separated by smaller satellites. The signal has been identified as arising from tetragonally distorted octahedral positions of $\mathrm{Mo}^{5+}$ ions.

- The IR Spectral studies indicate that the molybdenum ions occupy tetrahedral positions in larger concentrations in sample $\mathrm{M}_{5}$.

\section{REFERENCES}

[1] A. Murali, R.P.S. Chandrasekar, J.L Rao, Physica B. 19, 358 (2005).

[2] A. Paul, R.W. Douglas, Phys. Chem. Glasses 6, 212 (1965).

[3] J.L. Piguet, \& J.E. Shelly, J.A.M.Ceram. Soc. 68, 450 (1985).

[4] A.R. Kumar, J.L Rao, N.O. Gopal, Mater.Res. Bull. 40, 1256 (2005).

[5] J.L. Chakradhar, A. Murali, J. Rao, Alloys Compd . 29, 265 (1998).

[6] J. D. Lee, Concise inorganic chemistry, Blackwell science, Oxford (1996).

[7] Y. Dimitriev, J.C.J. Bart, M. Arnaudov, Z. Anorg, Allg Chem. 229,479 (1981).

[8] Y. Dimitriev, V. Dimitrov, M. Arnaudov, J. Mater. Sci. 18, 353 (1983).

[9] A. M. Milankovic, A. Gajovic, D.E. Day, J. Non-Cryst. Solids. 76, 325(2003).

[10] S. Simon, A.C. Nicula, J. Non-Cryst. Solids . 23, 57 (1983).

[11] J.F.Lyneh, S.L. Segel, G. Rosenblatt, J. Appl. Phys. 42, 2587 (1971).

[12] B. Bridge, N.D. Patel, J.Non-Cryst. Solids 27, 91 (1987).

[13] B.V.R.Chowdari, P. P. Kumari, Solid State Ionics 113, 665 (1998).

[14] P. Syam Prasad, M. Srinivasa Reddy, V. Ravi Kumar and N.Veeraiah, Philosophical Magazine. 87, 5763-5787 (2007).

[15] P. Syam Prasad, B.V.Raghavaiah, R.Balaji Rao, C. Laxmikanth, N.Veeraiah, Solid State Comm. 132, 235 (2004).

[16] H.Vichery, F. Rullier, J.Phys.France 50, 685 (1989).

[17] B. B. Das and R. Ambika, Indian Journal of Chem. 49, 425 (2010). 